\title{
Web-Based Monitoring Information System for Scholarship Holder
}

\author{
Dian Prijayanti ${ }^{1}$, Emilya Ully Artha ${ }^{2}$, Endah Ratna Arumi ${ }^{2 *}$
}

\begin{abstract}
${ }^{1}$ Student of Informatics Engineering Department, Universitas Muhammadiyah Magelang, Magelang, Indonesia.
${ }^{2}$ Department of Informatics Engineering, Universitas Muhammadiyah Magelang, Magelang, Indonesia.

*Corresponding author. Email: arumi@ummgl.ac.id
\end{abstract}

\begin{abstract}
Scholarship monitoring is one of the efforts made by institutions to monitor whether the student contribute to the institution or not. Monitoring also aims to increase the capacity of its human resources through education, Universitas Muhammadiyah Magelang is one of institution do this kind of monitoring. So far monitoring activities are carried out at the end of the semester, by collecting hard files at the Student and Alumni Development Institute (LPMA) face-to-face that causes data loss and duplication. The monitoring results are then recapitulated by the scholarship working group to determine the number of activities carried out by students to be used as a reference for the next scholarship. This research resulted in a monitoring information system to facilitate the working group in the field of scholarships and the Chairperson of LPMA in issuing a decision letter for further scholarship recommendations, so students can find out whether they passed or did not qualify based on the results of the monitoring. From the results of trials using Blackbox testing obtained valid results for all features displayed, and acceptance testing conducted with LPMA respondents and students obtained $79 \%$ assessment results, which means that respondents agree with the system.
\end{abstract}

Keywords: information systems, scholarships, monitoring, likert scale

\section{INTRODUCTION}

Every Indonesian citizen must be able to improve education to advance a country, to increase the role of education in competing with other countries [1]. Achievement students and alumni are one aspect of educational progress at the university [2]. Scholarships are financial help provided to outstanding students who aim to be used in the continuity of education being pursued [3], by providing scholarships as a forum for outstanding students to improve the quality of good education. Information technology can be used as a form of ICT use in the field of Education [4].

Universitas Muhammadiyah Magelang every new academic selects the choice of internal scholarships, namely Academic and Non-Academic to guarantee the right of every student to get quality education and to improve the quality of students (students) in Higher Education in the academic and non-academic fields, and makes it easier to check the process, and progress of student learning outcomes [5] [6]. The first selection of scholarship receipts includes the completeness of the files, and interviews. Furthermore, selection will be made by the admission of new students to decide the results of scholarship acceptance. After passing the scholarship selection, students are required to collect Study Result Cards (KHS) and monitoring student activities, with a condition of IP above 3 (three) and a minimum of 2 (two) activities. However, it is necessary to make sure that the scholarship award is right on target and has a positive impact on the academic activities of the students concerned, so that monitoring activities are needed according to the activities of the scholarship recipients. This activity is as an evaluation material for the achievement of scholarship acceptance as well as for recommendations for awarding further scholarships.

The Student and Alumni Development Institute (LPMA) at the University of Muhammadiyah Magelang has a Working Group (Pokja) in the field of scholarships that deals with data collection, and summarizes the results of monitoring to be subsequently recommended to the Chairperson of LPMA. There are several problems in implementing the scholarship monitoring data management which is conducted face-to-face, so that data loss and duplication often occur. To overcome these problems, a Website-Based Scholarship Recipient Student Activity Monitoring Information System is needed that can attach the name of the activity, date of activity, place of activity, photo evidence of activities, and Study Result Card (KHS) to be used as a monitoring report on the activities of scholarship recipient students, so that it can make it easier for students to collect monitoring files and scholarship work groups to check data entered in the system to see the development of advanced scholarships.

\section{METHOD}

\subsection{Flow map System}

The system flow map in Figure 1 is designed to explain the entire flow of the monitoring system created. The first stage in the monitoring system is that students fill out the registration form to get a username in the monitoring 
system, then students can start inputting the activities being carried out including uploading photos and IPs in the semester. After the students input the activity, then the administrative committee checks the data entered in the system, then checks the suitability of the file for monitoring requirements. After that the admin group of workgroups confirms to the chairman of the LPMA to confirm the results of monitoring the incoming documents to issue a recommendation letter on whether or not the new scholarship application is accepted or rejected.

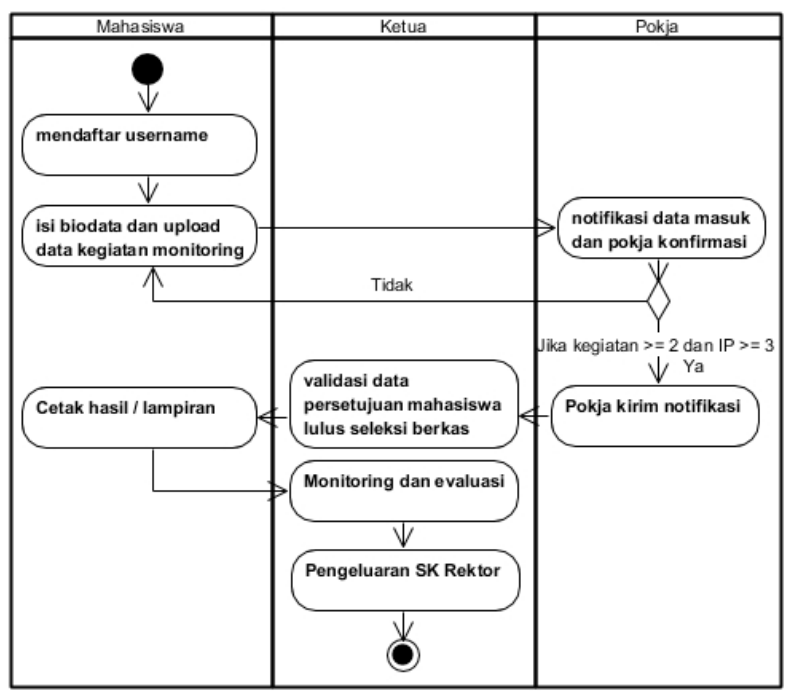

Figure 1 Flow map System

\subsection{Design System}

The main purpose of system design is to give an overview of the design of the system to be built or developed, and to understand the flow of information and processes in the system through the depiction of Use Case Diagrams, Class Diagrams, Activity Diagrams, and Sequence Diagrams.

\subsubsection{Use Case Diagram}

Use Case diagram can be seen in Figure 2 which involves three actors, namely scholarship recipient students, working group (admin) in managing monitoring files, and LPMA chairman who validates student activity data. Each actor has access restrictions in the system, namely students registering, then uploading activity data and printing monitoring reports, the working group can view data, print reports and drop student access, while the LPMA chairman can view all student monitoring files and validate the results.

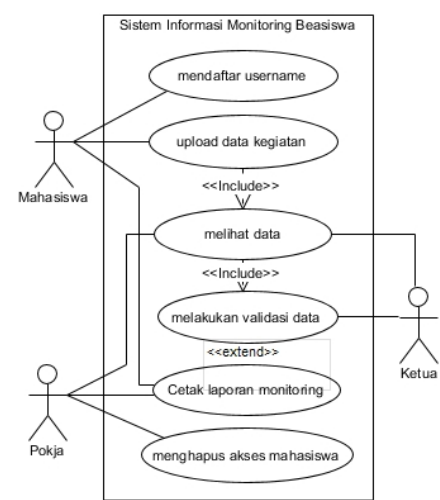

Figure 2 Use Case Diagram

\subsubsection{Activity Diagram}

The activity diagram in Figure 3 explain the Activity diagram that illustrates the activities that occur between students, scholarship working groups, systems, and LPMA chairmen. Students log in and input the monitoring activity data, then the confirmation working group and check the data, the working group will provide a warning letter for students with inadequate or incompatible files, if the file is appropriate then it is approved by the head of the LPMA and students can print the monitoring results.

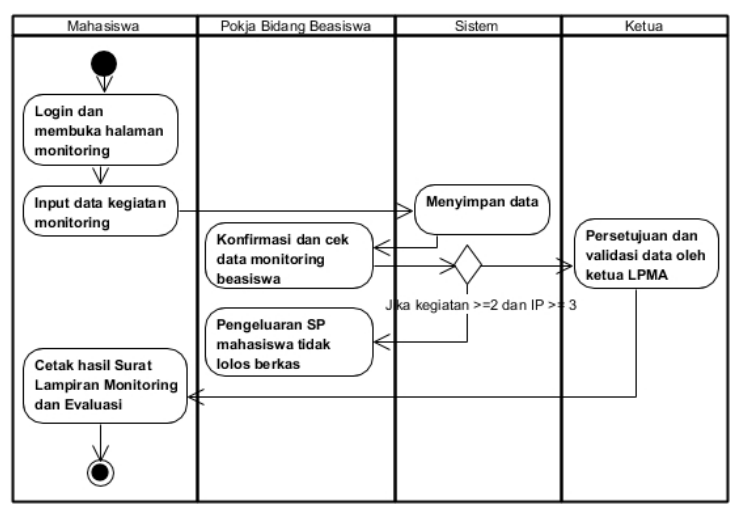

Figure 3 Activity Diagram

\subsubsection{Sequence Diagram}

Adding sequence diagrams illustrate student steps to add or input monitoring data. After that the results will be stored in the monitoring database.

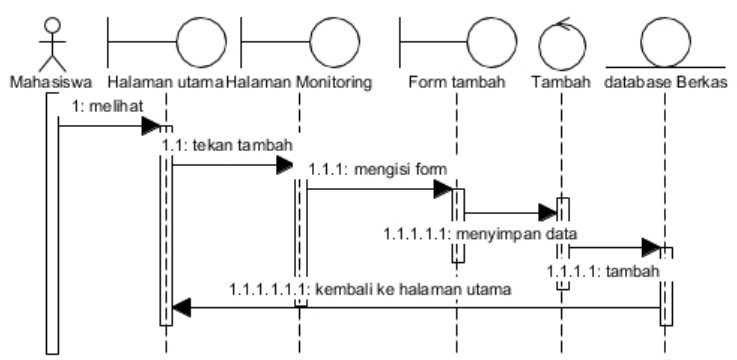

Figure 4 Sequence Diagram Adding Activity Data 


\section{RESULTS AND DISCUSSION}

\subsection{Design Interface}

\subsubsection{Interface Input Activities Data}

The design of this interface is to facilitate students in inputting activity data.

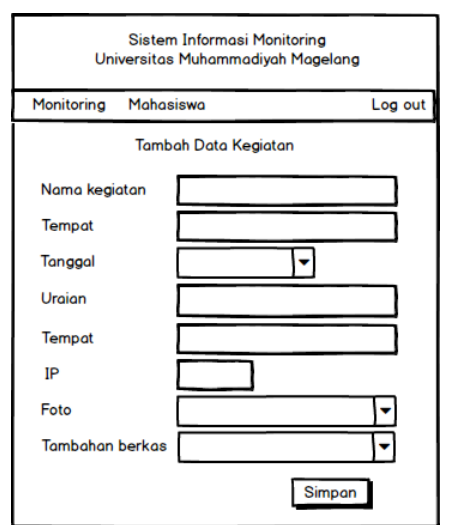

Figure 5 Interface Input Activities

This page displays a form for filling in the monitoring data by students. Then the data will be entered into the monitoring database, to further examine the completeness of the file by the working group.

\subsubsection{Interface Validation Page}

The validation page is used to display student data and monitoring data from students.

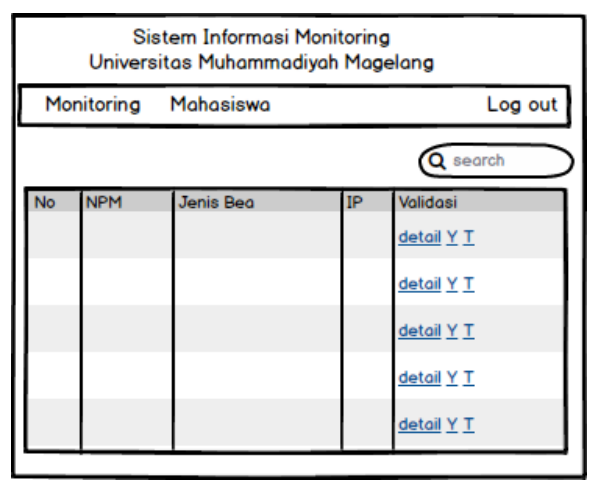

Figure 6 Interface Validation Page

This page displays the data of students who have registered on the system and the results of monitoring from students. Then after the working group checks the suitability of the student monitoring file, it will be validated by the chairman of the LPMA.

\subsubsection{Interface Printed Page}

Figure 7 is the printed page is used to display the results of monitoring of all students, both those accepted and rejected by the head of the LPMA. The results are in the form of student data with the condition that if accepted, the NPM and the name of the student will be printed in bold or bold in the form of a PDF of the recommendation for further scholarship acceptance and students can print for payment terms in the following semester.

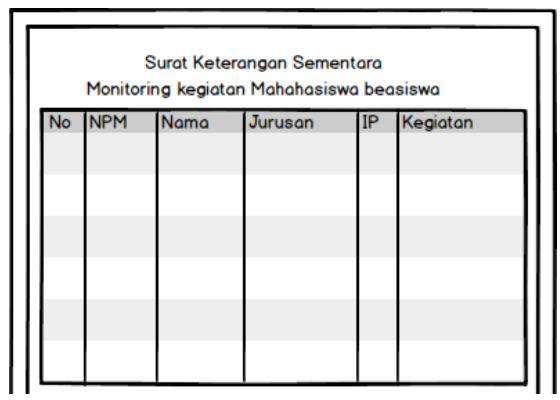

Figure 7 Interface Printed Page

\subsection{Result}

This study aims to produce a Monitoring Information System for Scholarship Recipients at the University of Muhammadiyah Magelang. This system will be tested by system users to determine the suitability of the needs in LPMA with black box testing and accepting testing. With the existence of a Monitoring Information System for Scholarship Recipients is expected to help related parties manage the activities of scholarship recipient student monitoring. The system is implemented with a website based.

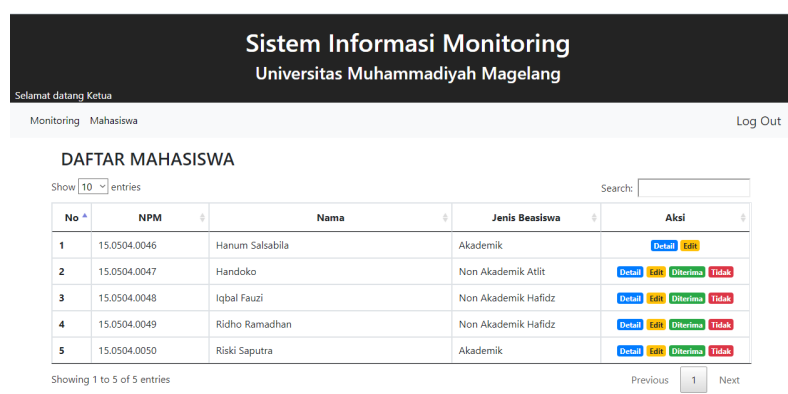

Figure 8 Validation Page by The Chairman

Figure 8 shows the validation page by the chairman of the monitoring results submitted by students. On this page there is NPM, name, and type of scholarship, then pressing the detail button will display activity data from the student. 


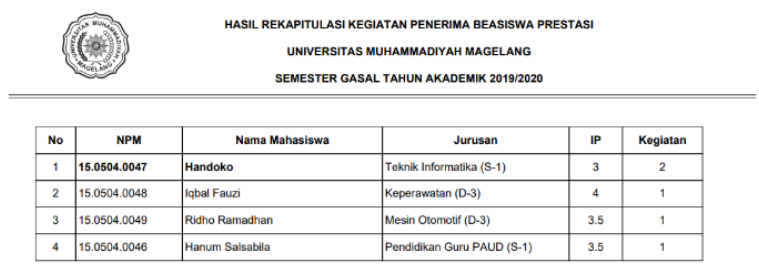

Figure 9 Print the Result of Monitoring

Figure 9 shows the results of monitoring that have been validated by the Chair of LPMA. Students can find out whether they are accepted and get further scholarships or are rejected and get a warning letter from LPMA which will then be monitored and evaluated with students face to face.

\subsection{Discussion}

The Scholarship Recipient Monitoring Information System is used by the Chairperson of LPMA and the Working Group in managing the results of monitoring student activities. This system is by the design of the system made, the user interface is by the initial design, and the database used is by needs. The system can be useful for the working group and chairperson in issuing recommendation letters for further scholarship acceptance, and passing the monitoring results file for students.

The advantage of this monitoring system is that students can upload photos of activities directly, and can find out the files that have been passed from monitoring results that have been validated by the chairman. Working groups and leaders can monitor every activity carried out by students without having to wait for the collection of files at the end of the semester. The print feature of the monitoring results in the form of a pdf is also very helpful for the working group and the chairman in issuing a certificate of recommendation for the continued scholarship. The weakness of this system is that there is no notification of further scholarship acceptance and a menu feature for changing passwords.

\subsubsection{Black Box Testing}

Black box testing is carried out by 3 users, namely the chairman, working group and students. Testing the login page is to verify the user data with the scenario of inputting the id and password for the expected results i.e. successful login, if successful then get a valid result. Testing about menu, to test whether the system can display monitoring requirements, the scenario is to click on the about menu. The chairman and the working group conduct a student page test, to test whether the system can display student data, if successful it will go to the student page where there is all the contents of the monitoring data. The Working Group conducts a test to see activity data and removes access for students who have not received scholarships, then the chairman tests the validation feature of student monitoring data results. Students test 2 (two) menus, namely on the student menu, they can complete their personal data, then the monitoring menu can add data, delete data, and edit the inputted activity data. Based on the results of black box testing conducted on 3 (three) actors, it can be concluded that all features available on the system are valid.

\subsubsection{Accepting Testing}

At this stage the system testing to prospective users is done, this stage is done by subjective assessment using acceptance testing, by distributing questionnaires [8]. The range of questionnaire assessment to measure respondents' attitudes and opinions was obtained using the Likert scale method. With this Likert scale, respondents were asked to complete questionnaire questions to show their level of agreement with the system that was created [9]. The distribution of questionnaires given to 12 (twelve) respondents, namely LPMA and students with 9 (nine) questions, showed a satisfaction rate of $79 \%$ which means the user agreed with the system created, because it could help the LPMA in issuing a certificate of further scholarship recommendations and students in passing the results of monitoring.

\section{CONCLUSION}

From the results of research conducted, it can be concluded that is based on all the results of the black box test, that the system can function as needed. While the results of accepting testing show the value of Satisfaction by users $79 \%$ so it can be said that the system that has been made can help students, working groups and LPMA chairmen in managing the results of monitoring scholarships at Muhammadiyah University, Magelang.

\section{REFERENCES}

[1] H. Wardhana and B. D. U. Hasanah, "Aplikasi Monitoring Penerima Beasiswa Bidikmisi Berbasis Web, Android Dan Sms Gateway," J. Matrik, vol. 16, no. 1, p. 22, 2018.

[2] A. Saputra \& Nugroho, "Perancangan dan implementasi survei kepuasan pengunjung berbasis," $J$. Ilm. Teknol. Inf., vol. 15, no. 1, pp. 63-71, 2017.

[3] M. Shodiq, K. I. Satoto, and R. Kridalukmana, "SIMBES, Aplikasi Manajemen Beasiswa di Universitas Diponegoro Berbasis Framework Code Igniter dan MySQL," J. Teknol. dan Sist. Komput., vol. 1, no. 4, pp. 86-92, 2013.

[4] M. Maimunah and E. R. Arumi, "Upaya Pengembangan Bakat Kreatifitas Bagi Siswa Smk Melalui Pembuatan E-Book Interaktif," in Seminar Nasional Hasil Penelitian dan Pengabdian Pada Masyarakat IV Tahun 2019, 2019, pp. 584-590. 
dan Ilmu Komput. Univ. Brawijaya, vol. 2, no. 12, pp. 7173-7182, 2018.

Belakang, D. Pendidikan, and K. Pekalongan,

"Penerapan Framework Codeigniter Dan Library Ion Auth," no. Islam, 2017.

[6] E. R. Arumi and U. Yudatama, "Pemanfaatan Curiculum Vitae dan Sasaran Kinerja Pegawai untuk Penilaian Kinerja Dosen Menggunakan AHP," J. RESTI (Rekayasa Sist. dan Teknol. Informasi), vol. 1, no. 3, pp. 170-176, Nov. 2017.

[7] F. Gerit John Rupilele et al., "Management Information System for Monitoring and Inspection of the Implementation of Universities," Int. J. Eng. Technol., vol. 7, no. 2.13, p. 451, 2018.

[8] E. Sutinah, G. N. Azima, and E. F. Imaduddin, "Sistem Informasi Monitoring Akademik Dan Prestasi Siswa Dengan Metode Waterfall," Journal of Information Engineering and Educational Technology, vol. 2, no. 1. p. 47, 2019.

[9] M. B. D. Nugroho, "Pengembangan Sistem Informasi Monitoring Pengadaan Barang Atau Jasa Berbasis Website Dengan Metode Rational Unified Process (RUP) (Studi Kasus : Unit Bisnis Jasa O \& M 2 Luar Jawa PT PJB Surabaya)," J. Pengemb. Teknol. Inf.
[10] ; Aprisa and S. Monalisa, "Rancang Bangun Sistem Informasi Monitoring Perkembangan Proyek Berbasis Web (Studi Kasus: Pt. Inti Pratama Semesta)," J. Ilm. Rekayasa dan Manaj. Sist. Inf., vol. 1, no. 1, pp. 49-54, 2015.

[11] . K., T. B. Setyaningsih, and A. Priswantoro, "Rancang Bangun Sistem Informasi Dokumentasi Kegiatan Science Techno Park Berbasis Web Pada Pusat Inovasi LIPI," J. Teknol. Inf. dan Ilmu Komput., vol. 3, no. 3, p. 174, 2016.

[12] A. B. Mutiara, A. Rifky, A. Muslim, and O. Teddy, “Testing Implementasi Website Rekam Medis Elektronik Opeltgunasys Dengan Metode Acceptance ...," Semin. Ilm. Nas. Komput. dan Sist. Intelijen (KOMMIT 2014), vol. 8, no. October, pp. 1-7, 2014.

[13] J. Lemantara, N. A. Setiawan, and M. N. Aji, "Rancang Bangun Sistem Pendukung Keputusan Pemilihan Mahasiswa Berprestasi Menggunakan Metode AHP dan Promethee," Jnteti, vol. 2, no. 4, pp. 20-28, 2013. 